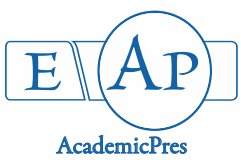

Haroon SA et al. (2021)

Notulae Scientia Biologicae

Volume 13, Issue 4, Article number 11083

DOI: $10.15835 / \mathrm{nsb} 13411083$

Note

\title{
Molecular and morphological characterization of Globodera rostochiensis (Wollenweber, 1923) Skarbilovich, 1959 from Egypt
}

\author{
Sanaa A. HAROON ${ }^{1}$, Zafar HANDOO ${ }^{2 *}$, Mihail KANTOR ${ }^{2}$, \\ Andrea SKANTAR ${ }^{2}$, Maria HULT ${ }^{2}$

\begin{abstract}
${ }^{1}$ Fayoum University, Faculty of Agriculture, Plant Protection Department, Fayoum, Egypt; sanaaharoon1951@gmail.com ${ }^{2}$ Mycology and Nematology Genetic Diversity and Biology Laboratory, USDA, ARS, Northeast Area, Beltsville, MD 20705, USA; zafar.handoo@usda.gov (*correspondingauthor);mihail.kantor@usda.gov; andrea.skantar@usda.gov; maria.hult@usda.gov
\end{abstract}

\begin{abstract}
The golden potato cyst nematode, Globodera rostochiensis (Wollenweber, 1923) Skarbilovich (1959) is a damaging soilborne quarantine pest of Solanum tuberosum (potato) and other solanaceous crops worldwide. In spring of 2021 a survey was conducted in area of Abo El Matamer, Bahera governorates in Egypt. Soil samples were taken in zigzag pattern throughout 65 acres of potato cultivated land and processed in Nematology lab, Fayoum University, Egypt. In June 2021, two hundred soil samples were collected from nearby areas to evaluate the distribution of this potato cyst nematode in other cultivated land located in area of first infection but fortunately the golden potato cyst nematode was not detected from neighboring locations. The nematode species was identified by both morphological and molecular means as Globodera rostochiensis. To our knowledge this is the first molecular and morphological characterization of $G$. rostochiensis from Egypt.

Keywords: Egypt; Globodera rostochiensis; PCN; potato

\section{Introduction}

Golden nematode, Globodera rostochiensis, is one of the three potato cyst nematodes (PCN) which are economically important pests of potato and have a worldwide distribution (Gartner et al., 2021). Globodera pallida and $G$. rostochiensis can cause potato crop losses of approximately $9 \%$ worldwide (Turner and Subbotin, 2013). Cyst nematodes are one of the most important pest groups of economically important crop plants in Egypt (Ibrahim et al., 2017). A survey conducted over a period of four years in three governorates of Alexandria, El Behera and Sohag by Ibrahim et al. (2017), found and identified G. rostochiensis along with other cyst nematodes. The detection of the golden cyst nematode G. rostochiensis on potato in El-Nobarria, El-Behera governorate in northern Egypt is very important as this nematode species has been considered as a serious and a potential pest on potato and other solanaceous vegetable crops (Ibrahim et al., 2017). However, that study did not provide any morphological or molecular characterization of $G$. rostochiensis. In the present study, the surveyed area included the Abo El Matamer and the neighboring areas located in Behera governorate.
\end{abstract}

Received: 17 Sep 2021. Received in revised form: 03 Nov 2021. Accepted: 05 Nov 2021. Published online: 11 Nov 2021.

From Volume 13, Issue 1, 2021, Notulae Scientia Biologicae journal uses article numbers in place of the traditional method of continuous pagination through the volume. The journal will continue to appear quarterly, as before, with four annual numbers. 


\section{Materials and Methods}

A nematode survey was conducted between April and May of 2021 in the Behera governorate. Two hundred samples $(250 \mathrm{~g} / \mathrm{each}$ ) were collected randomly in a zigzag pattern from about 65 -acre field cultivated with potato. The samples were processed by the Nematology lab, Fayoum University, and the cysts were extracted from the soil samples using centrifuge floatation techniques (Ayoub, 1980). Juveniles were fixed in $3 \%$ formaldehyde and processed to glycerin by the formalin glycerin method (Hooper, 1970; Golden, 1990). Females and some cysts were typically removed from roots after fixation for 12 hours in $3 \%$ formaldehyde solution. Photomicrographs of the specimens were made with a Nikon Eclipse Ni compound microscope using a Nikon DS-Ri2 camera. Measurements were made with an ocular micrometer on a Leica WILD MPS48 Leitz DMRB compound microscope. All measurements are in micrometers unless otherwise stated. Living nematode juveniles (J2) recovered from the cysts were examined morphologically and molecularly for species identification and by using key to species by (Golden, 1986; Subbotin et al., 2010). DNA was extracted from three specimens using the worm smash and proteinase $\mathrm{K}$ protocols as described by Skantar et al. (2020). Mitochondrial cytochrome oxidase I (COI) was amplified with primers Het-Cox1F (5'TAGTTGATCGTAATTTTAATGG -3') and Het-Cox1R (5'-CCTAAAACATAATGAAAATGWGC $\left.3^{\prime}\right)$ as described in the study of Subbotin et al. (2017). The following thermal profile was used for COI gene amplification: 4 min at $94^{\circ} \mathrm{C}$, followed by 40 cycles of 1 min at $94^{\circ} \mathrm{C}, 1 \mathrm{~min}$ at $45^{\circ} \mathrm{C}$ and $1 \mathrm{~min} 30$ s at $72^{\circ} \mathrm{C}$, with a final extension at $72{ }^{\circ} \mathrm{C}$ for $10 \mathrm{~min}$. PCR amplicons of 550 bp were cleaned with the Monarch DNA Gel Extraction Kit (NEB, Ipswitch, MA) and sequenced directly with the same primers at Genewiz, Inc. The newly generated DNA sequence was submitted to GenBank under accession number MZ570875.

\section{Results and Discussion}

\section{Measurements}

Cysts $(\mathrm{n}=5)$ were light brown in color, spherical to subspherical shape with a protruding neck, circumfenestrate. Anal area prominent. Vulval region intact or fenestrated with a single circumfenestrate opening. Vulval bridge and under bridge present. No bullae. Cyst wall patterns were ridge-like to wavy lines.

Cysts body length without neck ranged from 600-795 $\mu \mathrm{m}$ with a mean of $669 \mu \mathrm{m}$. The fenestra diameter range was between 16-20 $\mu \mathrm{m}$, with a mean 18.2 $\mu \mathrm{m}$. Distance from edge of fenestra to anal area was 70.0-95.0 $\mu \mathrm{m}$ with a mean of $79.0 \mu \mathrm{m}$. Number of cuticular ridges between anus and fenestra edge were 17-21, with a mean of 19.5 and Granek's ratio was 3.5 to 5.4, with a mean of 4.6. Measurements of second-stage juveniles (J2) from Egypt $(\mathrm{n}=15)$ included length of body tapering at both ends with more so in the posterior region (range $=463-500 \mu \mathrm{m}$, mean $=463 \mu \mathrm{m})$, stylet short, well developed $(20.0-21.5 \mu \mathrm{m}, 20.7 \mu \mathrm{m})$ with rounded basal knobs, lateral field with four lines. Tail $(43.0-56.0 \mu \mathrm{m}, 50.6 \mu \mathrm{m})$, tapering to bluntly rounded terminus and hyaline tail terminus measures $(16.0-32.0 \mu \mathrm{m}, 23.2 \mu \mathrm{m})$. Morphometrics of J2's including shapes of the tail, tail terminus, stylet knobs and cyst morphometrics and morphology were consistent with $G$. rostochiensis as given in description and or re-descriptions (Golden and Ellington, 1972; Mulvey and Golden, 1983; Subbotin et al., 2010).

Morphological characters used for identification included cyst shape, characteristics of cyst terminal cone including nature of fenestration, cyst wall pattern, anal-vulval distance, number of cuticular ridges between anus and vulva, and Granek's ratio. The second-stage juvenile morphologies critical for identification were the following: body and stylet length, shape of stylet knobs, shape and length of tail and hyaline tail terminus, and number of refractive bodies in the hyaline part of tail. The morphology of cysts and second-stage juveniles and molecular analyses established the identity of the species as the golden cyst nematode Globodera rostochiensis (Wollenweber 1923) Skarbilovich, 1959 (Figure 1). Diagnosis as G. rostochiensis was clearly confirmed by molecular means as well. 

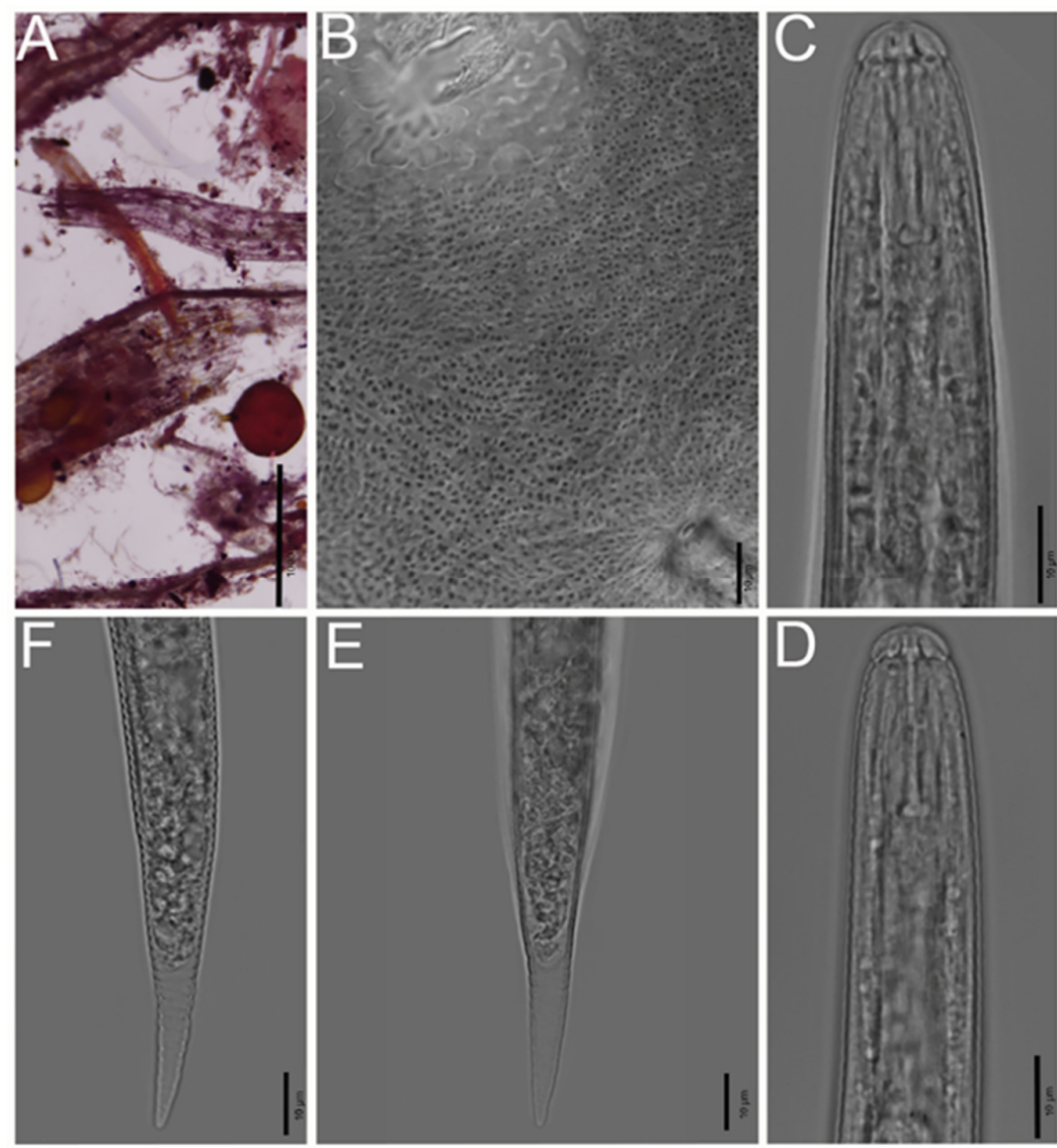

Figure 1. Golden nematode cysts extracted from the soil and root samples of potato cultivar Spunta (El Khatatba Area, Egypt). A: cysts; B: posterior end showing the vulva and anal openings; C, D: anterior end of J2's; E, F: posterior end of J2's.

\section{Molecular analysis}

DNA sequence (accession number MZ570875) was obtained for three amplicons representing three individual juveniles and aligned using Sequencher v. 5.4.6. All were found to be identical. A BlastN search of available sequences in GenBank revealed identity to $C O I$ sequences from several populations of Globodera rostochiensis, including MT240262 from Indonesia, MN095979 from Germany, MN095978 from Bolivia, MN095977 from Russia, and several others.

\section{Conclusions}

Based on the strength of mitochondrial COI to differentiate species of Globodera, it is confirmed that the Egypt population is G. rostochiensis.

\section{Authors' Contributions}

All authors contributed equally to literature research, writing, reviewing, and editing the manuscript. All authors read and approved the final manuscript. 


\section{Acknowledgements}

Mihail Kantor was supported in part by an appointment to the Research Participation Program at the Mycology and Nematology Genetic Diversity and Biology Laboratory USDA, ARS, Northeast Area, Beltsville, MD, administered by the Oak Ridge Institute for Science and Education through an interagency agreement between the U.S. Department of Energy and USDA-ARS. The authors thank Stephen Rogers of USDA-ARS, MNGDBL for technical assistance.

\section{Conflict of Interests}

The authors declare that there are no conflicts of interest related to this article.

\section{References}

Ayoub SM (1980). Plant nematology: An agricultural training aid (No. 632.6513 A983). NemaAid Publications.

Gartner U, Hein I, Brown LH, Chen X, Mantelin S, Sharma SK, ... Blok VC (2021). Resisting potato cyst nematodes with resistance. Frontiers in Plant Science 12:483. https://doi.org/10.3389/fpls.2021.661194

Golden AM (1986). Morphology and identification of cyst nematodes. In: Lamberti F, Taylor CE (Eds). Cyst Nematodes. New York: Plenum Press, pp 23-45.

Golden AM (1990). Preparation and mounting nematodes for microscopic observations. In: Zuckerman BM, Mai WF, Krusberg LR (Eds). Plant nematology Laboratory Manual. Amherst, MA: University of Massachusetts Agricultural Experiment Station pp 197-205.

Golden AM, Ellington DMS (1972). Re-description of Heterodera rostochiensis (Nematoda: Heteroderidae), with a key and notes on closely related species. Proceedings of the Helminthological Society of Washington 39:64-78.

Hooper DJ (1970). Handling, fixing, staining, and mounting nematodes. In: Southey JF (Ed). Laboratory Methods for Work with Plant and Soil Nematodes. 5th Edition. London: Her Majesty's Stationery Office, pp 39-54.

Ibrahim IKA, Handoo ZA, Basyony ABA (2017). The cyst nematodes Heterodera and Globodera species in Egypt. Pakistan Journal of Nematology 35(2):151-154.

Mulvey RH, Golden AM (1983). An illustrated key to the cyst-forming genera and species of Heteroderidae in the Western Hemisphere with species morphometrics and distribution. Journal of Nematology 15(1):1-59.

Skantar AM, Handoo ZA, Kantor MR, Carta LK, Faghihi J, Ferris V (2020). Characterization of Vittatidera zeaphila (Nematoda: Heteroderidae) from Indiana with molecular phylogenetic analysis of the genus. Journal of Nematology 52:1-8. https://doi.org/10.21307/jofnem-2020-024

Subbotin SA, Mundo-Ocampo M, Baldwin JG (2010). Systematics of the genus Globodera. Chapter 6. In: Hunt DJ, Perry RN (Eds). Systematics of Cyst Nematodes (Nematoda: Heteroderinae). Nematology Monographs and Perspectives 8A. Leiden, The Netherlands, Brill pp 107-177.

Subbotin SA, Akanwari J, Nguyen CN, Cid del Prado Vera I, Chihtambar JJ, Inserra RN, Chizhov VN (2017). Molecular characterization and phylogenetic relationships of cystoid nematodes of the family Heteroderidae (Nematoda: Tylenchida). Nematology 19:1065-1081 https://doi.org/10.1163/15685411-00003107

Turner SJ, Subbotin SA (2013). Cyst nematodes. In: Perry RN, Moens M (Eds). Plant Nematology. Wallingford: CAB International, pp 109-143. 
OPEN ACCESS

(c) (.)

The journal offers free, immediate, and unrestricted access to peer-reviewed research and scholarly work. Users are allowed to read, download, copy, distribute, print, search, or link to the full texts of the articles, or use them for any other lawful purpose, without asking prior permission from the publisher or the author.

License - Articles published in Notulae Scientia Biologicae are Open-Access, distributed under the terms and conditions of the Creative Commons Attribution (CC BY 4.0) License.

( $)$ Articles by the authors; SHST, Cluj-Napoca, Romania. The journal allows the author(s) to hold the copyright/to retain publishing rights without restriction. 